\title{
ADVERTISING MORALITY: MAINTAINING MORAL WORTH IN A STIGMATIZED PROFESSION
}

\author{
Andrew C. Cohen \\ Yale University \\ 493 College St. \\ New Haven, CT 06511 \\ andrew.cohen@yale.edu
}

\author{
Shai M. Dromi ${ }^{1}$ \\ Harvard University \\ 33 Kirkland St. \\ Cambridge, MA 02138 \\ shai.dromi@g.harvard.edu
}

\begin{abstract}
Although a great deal of literature has looked at how individuals respond to stigma, far less has been written about how professional groups address challenges to their self-perception as abiding by clear moral standards. In this paper, we ask how professional group members maintain a positive self-perception in face of moral stigma. Drawing on pragmatic and cultural sociology, we claim that professional communities hold narratives that link various aspects of the work their members perform with specific understanding of the common good. These narratives allow professionals to maintain a shared view of their work as benefitting society and to perceive themselves as moral individuals. As a case study, we focus on the advertising industry, which has long been stigmatized as complicit in exploitative capitalist mechanisms and cultural degradation. We draw on 9 total months of fieldwork and 74 interviews across three U.S. advertising agencies. We find that advertising practitioners use narratives to present their work as contributing to the common good, depicting themselves as moral individuals who care about others in the process. We analyze three prevalent narratives: the account-driven narrative, which links moral virtue to caring for clients; the creative-driven narrative, which ties caring to the production of meaningful advertisements; and the strategic-driven narrative, which sees caring in finding meaningful relationships for consumers and brands.
\end{abstract}

Keywords: Stigma / Professional ethics / Pragmatic Sociology / Cultural Sociology / Production of Culture / Narrative

This is a post-peer-review, pre-copyedit version of an article forthcoming in Theory \& Society.

${ }^{1}$ Both authors contributed equally and are listed alphabetically. 
For over two decades, Gallup polls have found advertising practitioners at the bottom of a list of professionals in terms of honesty and ethics, only narrowly beating car salespeople, telemarketers, members of congress, and lobbyists (Cardona 2001; Gallup 2015; Neff 2010). The American cultural landscape is replete with images of the morally questionable (if not downright corrupt) advertising professional, regularly represented as the "agent of the robber baron, manufacturing falsehoods to deceive a gullible public into buying useless products" (McDonough and Egolf 2015, p. 1083). The recent popular American period drama Mad Men, which follows the lives of those working at the fictional Sterling Cooper agency, further added to this image with its portrayal of advertising agencies as rife with sexism, racism, alcoholism, and adultery. Advertising professional Jon Steel (1998) wrote to his industry “... I would thus like to suggest that all advertising people reading this should pause for a moment, raise their eyes to the heavens, and give thanks for the very existence of car salesmen" (the only profession to rank lower at the time of writing; p. $\mathrm{x})$.

Its awry public representation notwithstanding, advertising appears to be an attractive avenue for employment. Depending on how an advertising agency is defined, the industry employs anywhere from over 190,000 people (Johnson 2015) to over 490,000 people (Statistic Brain 2015) in the United States. ${ }^{2}$ As a professional community, it includes a diverse array of skills and positions, including account managers, creative directors, art directors, copywriters, designers, account planners, market researchers, and digital developers, ranging from highearning CEOs to unpaid interns.

\footnotetext{
2 The definition of advertising agencies can be limited strictly to firms that develop traditional advertising, but can also be expanded to include digital marketing agencies, public relations firms, design studios, and research firms - in short, any organization that contributes to the collective activity of producing what audiences recognize as advertising (Becker 2008).
} 
Considering people tend to avoid stigmatizing situations when possible (Goffman 1959), we would expect people employed in a stigmatized industry like advertising to abandon their line of work (assuming they can afford to do so and are not coerced into such work). Thus, the liveliness of the advertising industry is puzzling because sociologists ranging from social psychologists to cultural sociologists have shown that individuals care deeply about being perceived as adhering to certain standards of morality (e.g., Baston, et al 1999; Burke and Stets 2009; Franzen and Pointner 2012; Stets and Carter 2012). Cultural sociologists in particular have demonstrated that concern about moral character is not only individual but also communal, as groups grapple together with ways to maintain a positive perception of themselves as good communities in face of outside challenges (Dromi 2012, 2014; Lamont 1992, 2000). Maintaining a sense of living up to a standard of moral worthiness is an essential component in maintaining dignity and a positive self-perception, on the individual and the communal level (Hitlin and Andersson 2015). Given these existing studies, we might have expected advertising to be far less attractive for employees than it currently is.

In this paper, we ask how a professional community like advertising maintains a collective sense of morality, and how it provides its constituent individuals with the means to present themselves as living up to a moral standard. Despite the rising scholarly interest in moral self-perception (Hitlin and Vaisey 2013; Lamont, 1992; Lamont et al. 1996), we still know little about how professional communities respond to the moral stigmatization of their industries, and how professional community members resolve questions about the ethical nature of the projects in which they are involved.

Drawing on work in cultural sociology (Alexander and Smith 2003) and pragmatic sociology (Bolanski and Thévenot 1999, 2006), we argue that professional communities 
maintain shared narratives that connect their work to broadly-defined conceptions of the common good. Actors in professional sectors draw on historically-constituted repertoires that define moral objects - real-world objects that benefit from their work - as well as a set of possible narratives to construe themselves and their activities as benefitting those objects. For example, employees in pharmaceutical industries might describe how their work benefits the patients or contributes to scientific knowledge, thereby depicting themselves as moral by virtue of caring for the common good. ${ }^{3}$ By contrast, when former CEO of Turkin Pharmaceuticals Martin Shkreli described his work as oriented toward profit at the expense of others, he rose to the status of "the most hated man in America" (Owles 2017). Cultural repertoires such as these circulate and reproduce through employee training, through common texts and stories that exemplify professional success, or through formal ethical codes (Wherry 2012). These repertoires provide individuals with ways to construct narratives that conceptualize their work as morally worthy, and to depict themselves as moral individuals in the process. By employing narratives about the links between the work their professional community pursues and broad ideas about the social good, individuals help maintain a common culture that confirms their moral identity. In making these claims, we follow Boltanski and Thevenot (1999) in seeing individuals as proffering justification about the righteousness of their work by drawing on

\footnotetext{
${ }^{3}$ As Hitlin and Vaisey (2013) claim, one branch in the sociology of morality evaluates individual behaviors and attitudes against universal ethical standards (e.g., fairness), whereas the other branch studies the forms of moral beliefs (i.e., their origins, dynamics, and consequences). This paper falls squarely within the purview of the latter studies. In this, we follow Boltanski and Thévenot's (2006) understanding of morality, which denotes aligning one's conduct or reasoning with one of the socially acceptable ways of defining the social good. We do not use the term moral in this paper in reference to Aristotelian virtue ethics or to Kantian categorical imperatives.
} 
collective systems of meaning and logic that prescribe specific understandings of a common good and how it should be achieved.

To observe these cultural operations of qualification in action, we analyze how advertising professionals frame the moral worth of their work, as they seek to depict themselves as moral individuals. The ethnographic and interview-based research of three advertising agencies we present in this paper demonstrates that advertising agency employees are aware of the perceived dubious moral value of their profession. Our analysis shows that advertising practitioners draw on common narratives that connect their work to various conceptions of the common good, emphasizing the good service they believe advertising can provide to society. These narratives allow advertisers to conceptualize advertising as a morally worthy endeavor, and of themselves as living up to their moral standard. We describe three prevalent narratives employed by advertising professionals: the account-driven narrative, which links moral virtue to caring for the clients who hire the advertising agency; the creative-driven narrative, which ties the production of meaningful advertisements to providing society with engaging, thoughtprovoking advertisements and with artistic value; and the strategic-driven narrative, which construes the work of the advertising professional as helping consumers find good brands. After tracing their historical emergence and identifying key texts that exemplify them, we demonstrate how professionals use these narratives in everyday work situations and in interviews.

While the current study cannot evaluate the extent to which advertising professionals objectively abide by the moral standards their narratives prescribe, the analysis illuminates a rarely explored side of professional communities by demonstrating the ways advertisers uphold frameworks of moral meanings by which to maintain a positive self-perception. At the workplace, maintaining a positive self-perception is an essential aspect of job satisfaction and, as 
sociologists of work and occupations have shown, job satisfaction has a profound effect both physical and mental wellbeing (Fenwick and Tausig 1994; Kohn and Schooler 1982; Schieman, Whitestone, and Van Gundy 2006). However, existing studies have conceptualized job satisfaction in terms of stress, fulfillment, and wages, but not in terms of morality. Instead, much of the literature on job satisfaction focuses on job characteristics and complexity (Judge, Bono, and Locke 2000) or on personality traits and their relation to fulfillment at work (Judge, Heller, and Mount 2002; Judge et al. 2001). Other studies have looked at contradictions between institutional roles and perceived identity (e.g., in the case of LGBT ministers; Creed, DeJordy, and Lok 2010), but have focused on the micro-processes by which employees respond to such tensions without examining the broader cultural frameworks that develop in their professional communities. The current study thus sheds light on the ways individuals in professional communities draw on collective, patterned responses to potential challenges to their moral selfperception, thereby pointing to an important and unaddressed side of job satisfaction.

\section{NARRATIVES OF THE COMMON GOOD}

Narratives, then, allow individuals to interpret their work as reflecting and confirming their own moral standards. But how do individuals determine which moral standards are relevant for their professional surroundings and what types of explanations would be acceptable ways to signal them?

As Boltanski and Thévenot (2006) demonstrated, Western civil societies support multiple, mutually exclusive frameworks by which to conceive of moral worth. Actors invoke these frameworks when they construct narratives about the common good in order to justify their behaviors. For example, actors may claim that a certain land development is worthy because it 
would help the economy (thereby assuming that market worth is the way to evaluate the common good). Conversely, other actors may object and claim that this land development will impinge on the local public space and thus limit locals' ability to interact and socialize (thus assuming that the common good is comprised of good civics and community). ${ }^{4}$ These different frameworks of moral reasoning, or "worlds of justification," are systems of logics that define what is worthy and how worth can be identified (Boltanski and Thévenot 1999, 2006). As such, worlds of justifications exemplify what Gabriel Abend (2014) calls second-order morality - namely broad sets of assumptions, theories, stories, and logics that provide actors with the parameters for defining morality in their daily interactions.

These abstract notions of morality shape the types of narratives groups employ about moral conduct by providing socially acceptable ways of reasoning about moral value. Narratives rely on such logics of reasoning because they "allocate causal responsibility for action, define actors and give them motivation, ... and provide social approval by aligning events with normative cultural codes" (Smith 2010, p. 18). They thus allow the individuals who employ them to account for their ethical responsibility for the consequences of their actions, based on how they posit themselves within the context of their social relations and networks (Ricoeur 1967; 1970). ${ }^{5}$ By describing one's actions as benefitting others, a narrative defines the speaker as a care giver (or, in other words, as acting morally), affirms the relationship between speaker and beneficiary, and defines the type of social good that the speaker upholds. In this way, narratives are essential for moral identity verification. The notion of collective narratives and frames

\footnotetext{
${ }^{4}$ In contradistinction to Bourdieusian analysis, which sees moral positions as predictable based on individuals' socio-economic position, Boltanski and Thévenot (1999) put aside pre-existing knowledge about the actors and focus on the justifications they offer.

${ }^{5}$ For elaboration see Riessman (1994) and White (1973).
} 
informs us both on how situations that question advertisers' perceived identities are interpreted and invoked on the group level, and how individuals develop the cultural tools by which to maintain a positive self-perception.

One of the central codes underpinning narratives about morality is "caring for" versus “harming" others (Graham, Haidt, and Nosek 2009; Haidt and Graham 2009). Care, in this sense, is a common code by which individuals imagine their relationship with others and with their social group to present themselves as good people. For example, anthropologist Daniel Miller (1998) has shown how shoppers formulate the act of purchasing mundane goods at a store as an act of caring for others, in order to activate the social relations they cherish. By raising logics of reasoning such as "I am buying this snack for my daughter; she loves this brand!", shoppers bestow moral significance on the seemingly mundane experience of choosing one product over another, thereby confirming their self-perception as a good and caring parent. Such anthropological work aligns with social psychological work showing that caring for others bears significant moral salience (Wilhelm and Bekkers 2010). Scholars have also shown care as a moral code can motivate behaviors such as donating and volunteering both on the interpersonal and the generalized levels (Glanville, Paxton, and Wang 2016). Similarly, the accounts advertising professionals provide for their work - who and what they care for through their work, what role it plays in society, who it benefits, and what types of social goods it provides - bring to light they ways they conceive of their own moral worth. Such narratives offer one mechanism for advertising practitioners to verify their moral identity, especially when they believe they are otherwise perceived as immoral.

Finally, how do professional communities maintain repertoires to construct such narratives? Narratives about moral worth circulate through professional worlds through texts that 
formulate them. Gorski (2013) notes that systems of value are usually transmitted through two concurrent types of texts: formulaic elaborations of rules and procedures, such as instructions manuals and ethical guidelines, and stories that demonstrate such systems of value in action, such as success stories, myths, and legends (pp. 335-336). Indeed, Boltanski and Thévenot (2006) demonstrate that common documents like instruction manuals and ethical guidelines illustrate ways in which legitimate claims about worth can be constructed in one industry or another. Illouz (2014) further notes that bestselling books often formulate inchoate areas of moral uncertainty and provide narrative ways of resolving them (see also Dromi and Illouz, 2010). In professional settings, texts help structure what organizational actors see as both efficacious and legitimate strategies of action, while also identifying moral objects relative to which actors can judge the worth of their work (Ho 2009; Stark 2009; Wherry 2012). Following this line of reasoning, we suggest such texts - including industry trade books that circulate in professional communities - help define the moral objects workers in their industry might care for as well as how they, as individuals, can construe a narrative relation to them. Following a brief review of what we already know about the world of advertising practitioners, we analyze the moral objects for advertising professional as well as the narratives that point to them in detail.

\section{ADVERTISING: MORAL WORTH IN AN IMMORAL PROFESSION}

Very little work on the production of culture (or creative industries) has taken a serious look at the value - moral or otherwise - creative agents assign to their work. Some of the most influential research programs in the sociology of culture have taken a Gramscian approach to the study of culture as a whole, and have seen cultural forms as an expression and reinforcement of 
hegemonic social relations (e.g., Goldman 1992, O’Barr 1994, Williamson 2002). This view discounts whatever value the producers of culture assign to their work, and to supplant it with the assertion that culture production is shaped by the interests it serves (Ewen 2001; Grossberg 1988; Grossberg, Nelson, and Triechler 1991; cf. Schudson 1981). The Bourdieusian paradigm highlighted the stratification inherent to fields of cultural production and the ways in which positions in those fields affect and - to large extents - predetermine the type of work creative agents produce and the importance they ascribe to it (Bourdieu 1993, 1996; Koppman 2014; Mears 2011). Other studies in the production of culture have highlighted the links between sponsorship, interests, and cultural products (Blau 1992; Peterson and Anand 2004), and yet others have dealt with the exploitation and exclusionary practices prevalent in creative industries (Bielby and Bielby 1996, 2002; Dowd and Blyler 2002). While the importance of such studies is evident, they have moved interest further away from engagement with the accounts culture producers provide for their work. Although there have been several meaning-centered studies of sites of culture production in recent years (Bartmanski and Woodward 2015; Klett 2014; Klett and Gerber 2014; McCormick 2009), these studies have not yet approached the broader moral significance cultural products bear for their producers.

If scholars have not paid much attention to the role of moral thinking among culture producers, this has certainly been true for studies of the advertising sector. Sociologists and media scholars have a long history of thinking critically about advertising, and have tended to conflate the work of the advertising agency with the interests of the client (Schudson 1981, 1984; cf. Ewen 2001; Schor 2004). Advertisements came to the fore as the focus of the Frankfurt School's scathing critique of mass culture. Adorno and Horkheimer (1979) famously criticized the advertising industry both for its economic cooperation with mechanisms oriented at 
maintaining inequality and for the deceptive content it transmits. Herbert Marcuse (1964) similarly saw advertising as a central accelerator of social and cultural degeneration. Following Marcuse, Stuart Ewen (2001) argued advertising was an ideological tool of early $20^{\text {th }}$ century U.S. businesses for conscripting citizens into consumer culture. More recent studies in this vein have shown how the advertising business has been key in blurring the lines between the economy (which had to adopt cultural competencies in order to support a mass market) and culture (which has gradually become embedded in economic logic) (Illouz 1997). Advertising has also been scrutinized by race and gender scholars, receiving criticism for disseminating and perpetuating stereotypical cultural imagery of women and non-white people (Goffman 1976; O’Barr 1994).

These critiques notwithstanding, sociologists still know very little about how an actual advertising agency works, and as a result, tend to subsume the advertising professional community under the negative effects attributed to advertising as such (Moeran 1996; Schudson 1984). Advertising agencies, in this view, are solely motivated by economic interests, and are quite willing to deceive consumers for their own ends (or the ends of their clients). The few sociological studies that have been conducted in advertising agencies tend to focus on issues of gender, class, and cultural identity for the employees within those agencies (e.g., Alvesson 1998; McLeod, O'Donohoe, and Townley 2009; O'Boyle 2012). While these studies are suggestive of the broad interplay of social identities and workplace experiences, they tell us little about the ways advertisers understand their work, particularly what social good (if any) they believe they provide. Without a more nuanced understanding of the work advertising professionals do, we cannot fully understand how individuals in these institutions participate in making cultural products (Moeran 1996; Schudson 1984). 
The lack of attention to the moral stakes creative industry actors assign to their work is at odds with the expansive organizational studies literature that uncovers the frequent struggles about ethical standards in workplaces and professional communities (Ashforth and Reingen 2014; Besharov 2014). These struggles are oftentimes consequential for broad organizational processes and policies (Anteby 2010; Gehman, Treviño, and Garud 2013), a point exemplified in Robert Jackall's (2010) classic study of corporate managers, which drew attention to the multiple conundrums bureaucracies create and the painstaking (but also creative) ways in which actors navigate them in determining the ethically correct course of action.

Studies have also expanded beyond the intra-organizational scope, and have shown how some organizations - including hospitals (Heimer and Staffen 1998), the Motion Picture Association of America, and religious schools (Brophy 2014) - deal with 'real world' consequences of their policies. In such study cases, questions of right and wrong (and the accepted ways to resolve them) are embedded within a professional culture, informing interactions and decisions both within and between organizations. Similarly, historians have documented debates over the acceptability of practices such as political advertising, radio broadcast advertising, comparative advertising, and cigarette advertising that punctuate the history of the American advertising industry (Fox 1997; Sivulka 2012). Navon (2017) has shown that early-twentieth-century American advertising was justified as a public service, rather than a simple business investment, one that had assisted in World War I efforts and one that could be used to raise the standard of living by better educating consumers. Whereas the efforts of legitimization in this historical example were directed towards industry and government audiences, we can also expect the advertising community to harbor ways of thinking about and dealing with the consequences of its labor. 
Many types of markets, such as the market for cadavers (Anteby 2010), bodily organs (Healy and Krawiec 2012), and life insurance (Quinn 2008), espouse narratives that present their specific practices in a positive light. But studies of these markets have focused on how individuals and firms have worked to make the public consumption of their goods and services morally acceptable. These studies have not taken an interest in the ways those who work in such markets reflect on the broad effects of their work on society and maintain the belief that they are, in essence, moral persons. The same is true for studies of corporate social responsibility, which tend to analyze how organizations adopt and employ ethical policies but ignore the intermediaries - the employees themselves (e.g., Campbell 2006, 2007). ${ }^{6}$ Andrew Abbott's (1988) study of professions similarly looks at how professions seek new forms of legitimacy by making claims that are culturally acceptable, but does not examine how those claims affect professionals' self-perceived moral identities. Since advertising professionals remain stigmatized in the public sphere, and assuming ad makers are not universally morally bankrupt, how do they defend their own moral identities when their profession is perceived so negatively?

\section{METHODS}

The data for this article was gathered during a larger ethnographic research project, which aimed to explore the social processes of advertising production through participant observation and interviews. The first author spent nine months across 2013 and 2014 in three separate,

\footnotetext{
${ }^{6}$ The CSR studies that take employees into account usually look at the effect of CSR adoption on employee attitudes and behavior, but do not take an interest in their moral self-perception (e.g., Rupp et al. 2006).
} 
geographically dispersed American advertising agencies: Pioneer (PI), Alexander \& Sons

(A\&S), and CultureShock (CS), ${ }^{7}$ located in the Northeast, Midwest, and Rocky Mountain region of the United States, respectively.

Advertising agencies are complex networks of cooperative social arrangements, geared to produce advertisements for paying clients (cf. Becker 2008; Malefyt and Moeran 2003; Moeran 1996). In general, clients come to agencies with their business challenges - to increase sales during the holiday period, to introduce new products, or improve the company's public image, for instance. Teams from the advertising agency's different departments then collaborate to develop ideas for advertisements and - crucially - persuade the client to approve the product of those ideas. The sizes of these teams vary depending on the size of the agency, but most modern advertising agencies have at least three core departments: account management, with account executives who liaise between the client and the agency; creative services, with creative directors, copywriters, art directors, and creative directors who develop the ideas, words, and visuals that constitute the advertisements themselves; and account planning, with account planners (or strategists) who research consumers and the market to develop strategic insights that can inspire and provide legitimacy for creative ideas, while also measuring the success of campaigns.

\section{Interviews}

\footnotetext{
${ }^{7}$ All agency names, as employee names and brand names, are pseudonyms. Some product categories have been changed and some job titles have been generalized also to protect participant confidentiality. As per the institutional review board protocol, the first author's role as a researcher was disclosed to all three agencies and was common knowledge among his coworkers. Before observing and participating at any of the agencies, he signed an agency agreement for nondisclosure regarding the work. His role as a researcher did not interfere with his participation in the daily routines of the agency.
} 
During the fieldwork period, the first author conducted a total of 74 semi-structured interviews with 70 employees from the observed agencies. On average, these interviews lasted just over an hour and ten minutes. He recruited participants by requesting meeting times with agency employees, scheduling time either with the employees directly or with the employees' assistants (especially in the case of elite agency employees). Most interviews took place on-site during the workday, with a few exceptions of before- or after-work meetings. Participants included copywriters, art directors, designers, creative directors, account executives and supervisors, web and app developers, strategic planners and researchers, and user experience designers, ranging hierarchically from interns to company presidents and CEOs. Participants' ages ranged from 19 to late 60s. Just fewer than half the participants were women. Almost all participants were white, with three exceptions; at least four had national origins outside the United States. Almost all participants had at least a college education, with a few having master's degrees or having completed some kind of creative portfolio school (and sometimes both). ${ }^{8}$ All interviews, with the participants' consent, were recorded and transcribed word-forword. The interview protocol asked open-ended questions about participants' day-to-day experiences and their work histories, probing for their accounts and evaluations of the advertising process. Significantly, the interview protocol did not ask direct questions about morality, but the semi-structured approach to interviewing allowed the interviewer to probe further when interlocutors introduced the topic (Weiss 1995).

\section{[TABLE 1 ABOUT HERE]}

\footnotetext{
${ }^{8}$ The interviewer did not inquire directly about demographic information, but this data emerged throughout the fieldwork process. However, the interviewer did ask about educational background and training.
} 


\section{Participant observation}

Participant observation was conducted to observe the various routines of the advertising production process. In each agency, the first author gathered several weeks of observations before beginning interviews in order to ground each interview in the concrete context of his interlocutors' work routines and probe them about particular observations. In the latter two agencies, the first author also worked for the agency as an intern (cf. Koppman 2014; Rivera 2012).

Being the same ethnicity and age as (if not slightly older than) many of the entry-level employees (and some above entry-level) helped the first author avoid possible biases that his presence could have potentially caused. Furthermore, his presence at the firms as an intern allowed him to ask more questions and take field notes publicly with little scrutiny.

\section{Data Analysis}

Field notes and transcribed interviews were entered into the qualitative data analysis software NVivo. While the initial project sought to explore the social processes behind the creations of advertisements in advertising agencies, initial inductive coding called attention to themes of morality, particularly in moments when moral issues "bubble forth despite the efforts of the reasonable, honorable self to suppress it" (Pugh 2013, p. 57; cf. Rivera 2012). In many cases, these moments occurred in response to questions about what the participants liked and more importantly - disliked about the advertising industry, and what they would change about the industry if they could. These moments provided rich opportunities for interpretive analysis, in which we could hermeneutically reconstruct the frameworks interviewees use in their cultural 
work to justify their participation in the advertising industry (Boltanski and Thevenot 2006; Pugh 2013). In analyzing the interviews, we looked for ways in which interviewees talked about the implications of their work and how they attach moral worth to that work. We then grouped the key connections interviewees made between their work and specific conceptions of the common good, and identified the narratives that emerged.

\section{FINDINGS}

\section{Concerns with morality}

Many of the advertising practitioners interviewed were acutely aware of the pervasive stigma their profession carries, which they encounter in media representations and conversations with acquaintances.

$A C C$ : So how do you explain your job to other people, like someone you just met or at a family dinner?

Junior Strategist (CS): Oh geez. It's so corny. I usually say I am in advertising, and I get the fucking eyebrow raise, and then I say 'I swear to god, it's not as glorious as Mad Men.' You know, because people think that advertising is like, you know, we just sit around drinking, smoking all the time and don't ever work hard. Some people even think advertising is evil and have a huge chip on their shoulder about it.

Interns at both Alexander \& Sons and CultureShock, who were almost always new to the industry, voiced concerns about entering the industry in the first place. For instance, over a late weekend brunch in a local diner, Kira - an account executive intern at CultureShock - confided how she was worried about the bad moral reputation of advertising prior to starting her 
internship. Kira described how she had asked her supervisors about the morality of their own work, and how she hoped to do meaningful work that could change culture in a beneficial way.

This kind of concern ranged from entry-level employees to senior executives. A seasoned creative director at Culture Shock, whose lengthy career spanned several agencies, claimed that “[m]ost people joke and say they are not [morally good] and they are immoral ad a-holes, but for the most part, most good people I've work with genuinely care that they are doing the right thing. They really do."

Yet many of the practitioners interviewed had stories about being morally shamed for their profession. "Like, I remember after one of my intern parties [at a former agency], a cab was taking me to Union Station and he [the driver] asked me what I was doing," a copywriter at Alexander \& Sons explained. "I said I was in advertising, and of course I get the backlash: oh, why would you ever want to do that?"

Copywriter $(A \& S)$ : I got it yesterday - or no, I got it on Tuesday: 'Oh, you're in advertising? Oh, so you force shit on people.' Like, okay, you could look at it that way, or you could look at it a different way, you know? And I've been trying to look at it in a different way...

As the end of this excerpt demonstrates, these practitioners articulated a need to address the stigma of their industry and defend their moral identity. This need "bubbled forth" regularly in the open-ended interviews in particular (Pugh 2013). For example, a senior art director at Alexander \& Sons expressed her frustration, saying "You know, people tend to make fun of advertising [practitioners] like a car salesman, but it's not like that!' Later in the interview, she repeated the sentiment without prompt: "I wish people would think more of [advertising] than 'a used car salesman,' you know? There's a lot more to it than that!"

As these examples suggest, concerns with the moral perception of the profession are 
certainly present in advertising agencies. How do advertising professionals address such challenges to their collective moral identity? In the following sections, we show how the identity work advertising practitioners undertake employs patterned ways of linking the work they do to specific notions of caring and of the social good. The narratives that emerge here depict the professionals themselves as moral individuals in the process.

Linking morality to advertising work: clients, ads, and consumers

We identify three general patterns of narratives practitioners employed in discussing the moral value of their work: account-driven, creative-driven, and strategic-driven. These three narratives emerged in the field as part of three broad approaches to understanding different ideal types of advertising agencies in the advertising community, as summarized by the CEO at CultureShock:

$C E O(C S): \ldots$ there are creative driven agencies, there are account driven agencies and there are strategic driven agencies. ... It's like, a strategic-driven agency, you know just has to get the strategy [for the advertisements] right and everything else will take care of itself. An account service driven agency just has to have a great relationship with the client, and if work doesn't matter as much I can make the promises and make them happy and we can have a relationship. And the creative agency lives and dies on their work...

Broadly speaking, each of these narratives point in a different direction in linking the profession with the presumed positive effects on society: the account-driven narratives points to caring for clients, the creative-driven to the advertisement itself, and the strategy-driven to specific consumers. These moral objects are contingent on, and can be traced back to, particular shifts in the history of the American advertising industry. Practitioners in all three agencies used these 
narratives to frame their activities in ways where their work can match their moral identities; and in every agency, we found clear evidence of all three narratives. ${ }^{9}$

Furthermore, we found that each of these three narratives broadly correlated with various texts that practitioners tended to draw on when making claims. Three texts in particular exemplify this: for the account-driven narrative, David Ogilvy's ([1963] 2011) Confessions of an Advertising Man; for the creative-driven narrative, Luke Sullivan's (2003) Hey Whipple, Squeeze This; and for the strategy-driven narrative, Jon Steel's (1998) Truth, Lies, and Advertising. These trade books came up during field work as practitioners either referred to them in conversations or recommended them to the first author as a way to better understand the advertising industry. Along with these trade books, advertising practitioners would sometimes refer to other, similar trade books (such as Jean-Marie Dru's (1996) Disruption), video-recorded speeches from advertising professionals (such as famed advertising executive Leo Burnett's retirement speech) as well as from other famous personalities (such as a talk on creativity by comedian John Cleese), lessons from college or portfolio school (particularly quips from Mark Fenkse, an instructor and advertising professional who is also cited in Sullivan's (2003) book), and training materials and case studies from within the agency itself. By comparison, documents of formalized ethics from professional organizations in the industry - such as the Institute for Advertising Ethics's “Principles and Practices for Advertising Ethics" (Snyder 2011), which is

\footnotetext{
${ }^{9}$ Aside from the three narratives we present here, which were the most salient in our data, additional, less common narratives also circulated in advertising agencies in this study. One additional justifying narrative focused on how the work employees perform demonstrates loyalty to their agency and their colleagues, while another focused on how advertising work supports the economy and improves the standard of living. (The latter narrative bears similar logics to the one both Ewen (2001) and Navon (2017) identify in business and marketing journals from the early 20th century.)
} 
endorsed by the American Advertising Federation (AAF) - were never mentioned throughout the first author's field work. The diversity of texts mentioned in the field and the lack of references to overarching organizations like the AAF reflect the decentralized structure of the advertising industry as well as and the diverse educational and occupational backgrounds of advertising practitioners on the other hand. ${ }^{10}$ While other narrative frames also circulate among advertising professionals, especially through industry publications such as Ad Age (Cohen 2016), we present here the most salient scripts in our data to demonstrate key ways in which these individuals contend that they contribute to the greater good.

\section{[TABLE 2 ABOUT HERE]}

\section{Account-driven: care through expert solutions}

The first major narrative we identified was the account-driven narrative, in which agents justify their moral worth by framing their work as helping their clients. This narrative emerges early in the history of the advertising industry. When advertising agencies first emerged in the United States in the 1840 s, they did not prepare advertisements for clients; instead, early advertising agents bought advertising space in newspapers wholesale and sold it to advertisers piecemeal, at higher rates (Fox 1997; Sivulka 2012; Tungate 2007). While neither the advertisers nor the newspapers knew the rates the other used with the advertising agents, both parties tolerated the

\footnotetext{
${ }^{10}$ While a majority of the interns at these agencies were college students with stated intentions to pursue careers in advertising, many of the full-time practitioners described having come to work in advertising by chance or by accident. For example, during an internal presentation at CultureShock, the head of account services said, "Nobody wakes up and says, 'I want to be in advertising' - except Mars fucking Alcantera [the head of account planning]." In response to this remark, the audience of agency employees laughed.
} 
dubious agents because they were nonetheless beneficial: the agents helped the newspapers sell space and create a sizable income stream, while helping advertisers with the time-consuming work of securing media space (Sivulka 2012). This practice significantly structured the advertising industry; even today, U.S. agencies pay media companies for space or time (depending on the medium), then bill the advertisers (Moeran 1996; Sivulka 2012). However, this arrangement shifted in the late $19^{\text {th }}$ century. The N. W. Ayer \& Son agency, founded by Francis Wayland Ayer in 1869, introduced the "open contract," a legal agreement between the agent and the advertiser with explicit, agreed-upon financial terms (Fox 1997; Goodrum and Dalrymple 1990). In the open contract, the agent is paid a commission of the publisher's fees. Although the agent was still more or less making its money from the media company, the open contract began to shift the agent's ties of loyalty away from the media companies and towards the client (Fox 1997; Goodrum and Dalrymple 1990; Moeran 1996). This type of arrangement became commonplace in the advertising industry as the open contract was mimicked by other agencies and demanded by other clients (Fox 1997). Significantly, this contract and its explicit terms fosters a new narrative framing, in which clients become the moral object for advertising agents.

David Ogilvy ([1963] 2011) echoed this narrative in Confessions of an Advertising Man when he wrote that the "relationship between a manufacturer and his advertising agency is almost as intimate as the relationship between a patient and his doctor" (pp. 69-70). Not only does this metaphor express a particular conception of the advertising practitioner's duty to their client, but also it describes a particular conception of expertise, which we discuss below.

In general, the account-driven narrative revolves around framing the work of advertising practitioners as exercising moral agency by helping their clients achieve their goals. 
Executive Producer $(C S)$ :... I like solving problems, and I think it's cool to have the opportunity to work on a variety of products where there are needs and problems [...] and I love to be able to create solutions that people need.

This framing was pervasive in interviews. Practitioners from every department discussed advertising as a creative solution to a client's business "problems" or "challenges." As a senior art director from Alexander \& Sons explained in an interview, "I love being able to solve visual problems for people and how to communicate things in a more streamlined way, and I love being able to grow their [the client's] business too. You know? If there's something I can do to help them succeed, then I want to do it.” Interviewees thus talked about caring about their clients as making the difference between leaving the office at 5 versus leaving at 9:

Senior Art Director $(A \& S)$ : ... I think that if you really care about what you're doing and you want to succeed and make the client happy, you'll probably say, 'okay, I'm going to stay late and get this done, because it's not - it doesn't feel, you know, 'what I think is right'."

Here the art director paints a picture of herself as someone who "really care[s]" about the client and wants to do what feels right. 'Obviously if the client is happy, you feel as if you've done a good job," an account director at Pioneer explained.

As the above illustrates, in the account-driven narrative advertising practitioners frame themselves as skilled experts who help others survive in a challenging marketplace. In the most extreme example, this goes beyond the immediate client to other stakeholders in the client's company.

Creative Recruiter $(C S)$ : What I love about the work we have done here for [a fast food client] is, when we did [their campaign], not only did we save a giant corporation from bankruptcy but - 
those are franchisee owners, so you basically were able to save small businesses too through the process.

Practitioners used this narrative in nuanced ways. While the narrative is about helping the client, merely doing what the client wants was not seen as acceptable. "How I think I'm doing a good job is, if I feel like I'm actually adding value. ... I want to be able to make sure that [what we give the client] is the right thing, as well," continued the account director. Practitioners from almost every department proffered explanations about how clients often don't know what they want or how they don't know what they actually need. Of course, what the client wants and what the practitioner thinks is right are not always identical.

VP, Account Planner $(C S)$ : I had a client I worked on [at a previous agency], [a] challenger razor brand to Gillette. And 'right' for them was if an ad said there are intended two message points and a copy test, and that's all they care about. ... I could have sold them a hundred spots that hit that mark but that wasn't right, because any time they did that, I knew in my gut and I knew from talking to consumers, that the second you show a razor ad with a demo, they think Gillette. So why would I let a client who needs my help go down the wrong path...? So we ultimately convinced them to do other things ... their sales were amazing. ... [W] hen they let us lead them and show them what was right, they would have amazing consequences.... If you do something that will fit in and not disrupt on the behalf of who you are doing it for, that's not right.

Account-driven justifications, then, portray practitioner as moral individuals when they help in the right way, that is, by using their own expertise, much like a doctor helps a patient. $C E O$, former creative director $(C S)$ : I mean, I was pre-med; I was going to be a doctor; it didn't work out. But I mean I see our role as doctors, whose brands are unhealthy, they have problems, and they need someone to be honest with them. Generally speaking, we think we are fighting with 
them, but you know, a doctor takes a Hippocratic oath, and you have to - you need to tell them that this is the problem, and you've got to face those problems. And I think that changes the dynamic, when you really want to see the true beauty inside a brand or company, and you want to share that with the world in an effort to make them more successful. And you are trying to create something that will last and that will truly solve their problems.

As the CEO suggests, there is a general narrative in the ad agencies about fighting with clients. Every agency had at least one client who was remembered as difficult enough that their name alone was a sufficient explanation for an employee's frustration. In each case, the story was about the client, for whatever reason, not seeing eye-to-eye with the agency on what kind of work should be done. To some employees at these agencies, this was frustrating, because it kept the agency employees from being able to provide what they believed was proper care:

Account Executive (A\&S): If you just committed a crime, are you going to hire a lawyer that knows what the fuck they are doing, [or] are you going to hire a lawyer whom you can tell how ... to do their job? No, you are going to hire a lawyer who is going to get you off for whatever it is you did! You are not going to tell the lawyer how to do the job ... You wouldn't hire a doctor to perform a surgery on you, and then tell the doctor how to perform that surgery on you.

Thus, while losing a difficult client may be an economic problem, it can also be experienced as a relief for the agency staff. At Pioneer, the management shared in an agency meeting that one of the clients may be going behind their back by hiring an "SEO shark" (a freelance search-engineoptimization specialist) to do the work instead. In response, their lead developer shrugged and cited an old adage: "Don't look a gift horse in the mouth," he grumbled, expressing how even though the agency may be losing work from the client, it was better to not have to deal with that particularly frustrating client. Similarly, at CultureShock, during a welcoming question-and- 
answer meeting in the agency's largest boardroom, the managing director told an audience of all the interns about how the agency had lost a hotel client shortly after one of the agency's wily producers physically assaulted a staff member at one of the client's hotels during a party. It was 'probably for the best,' the director said, given the difficulties the agency had with the client. Even though these cases mean economic loses for the agencies, violating market logics, they can also be used to demonstrate an identity of someone concerned about helping 'good' clients through the use of their expertise.

Conversely, framed in the account-driven narrative, work for what might be a morally reprehensible client becomes justifiable. For instance, one of the three agencies worked for a tobacco client, ${ }^{11}$ which - given the American stigma to tobacco and its advertising - was morally problematic. Yet practitioners had no trouble framing their work in such a way where the situation meaning allowed them to be morally good.

Account Services $^{12}$ : I try to balance it out. So when I was on the [account] that I felt like I just could not get behind, for me personally, I found the positives in it that I love the team, I loved the client people I was working with.

Creative Services: A lot of people sort of have a problem working on tobacco ... It's your own vice and we all have our vices but I think - I like to think that regardless of the end-product we still do a better job than our clients would get anywhere else. Like, tobacco's a very hard category to work in, there's a lot of legal constraint. ... I feel like we do our clients justice and so that they get a better job with us. We will give them a service that they couldn't get anywhere

\footnotetext{
${ }^{11}$ We have decided not to identify the agency for this client, and we have limited as much information as possible to protect the identities of our informants.

${ }^{12}$ For quotes regarding the tobacco client, we have removed specific titles and instead use only their department within the agency.
} 
else or at least they couldn't get better anywhere else, so for me that's like where I find the sort of satisfaction in my job regardless of the end result, the end product.

As these quotes demonstrate, the perceived morality of the work lies in helping out the clients themselves, regardless of the stigma the clients carry. The practitioners, particularly at the agency with the tobacco client, recognize the stigma their client carries; but at the same time, they articulate stories that depict them as moral people who care for clients, who dutifully perform their jobs, using their expertise, just as a doctor or a lawyer might, in order to empower them and move them in the right direction.

\section{Creative-driven: care through inspiring work}

The second major narrative we identified is the creative-driven narrative, in which agents justify the moral worth of their work with reference to making meaningful advertisements. Historically, the advertising agent's concern with the aesthetics of the advertisement itself does not emerge until the end of the $19^{\text {th }}$ century. After the American Civil War, the number of advertising agents increased rapidly as advertisers increased their production, railroads improved distribution channels and enabled national services, and magazines emerged as a new medium for advertising (Goodrum and Dalrymple 1990). As agencies competed against one another, they began offering more services to their clients. In particular, a handful of agencies rationalized their work by arguing that the details of their clients" "[a]rt, copy and layout had to be carefully considered to reflect the broader marketing strategy of product image, pricing, and distribution" (Sivulka 2012, p. 68). Whereas before advertisers had made their own advertisements and the agencies merely placed them, now agencies were beginning to assist with writing ads, producing artwork, specifying typefaces, and securing the best possible spots at the best possible prices in various 
media (Goodrum and Dalrymple 1990; Sivulka 2012). In the 1890s, agencies like N. W. Ayer \& Sons and Lord \& Thomas began hiring full-time, dedicated copywriters, incorporating a new division of labor between handling clients and creating advertisements (Sivulka 2012, p. 68); by the end of the century, writing copy became a standard feature of advertising agencies (ibid).

Dedicated art direction soon followed (Sivulka 2012). By this point, advertisers had already realized the value of the image that accompanied their advertisements. Newspapers had improved their abilities to print detailed illustrations, and magazines - following an issue of Youth's Companion magazine from 1893 - had begun to print full-page advertisements in fullcolor (ibid.). These changes helped "set the stage for the illustrators who would dominate advertisements well into the twentieth century" (p. 64), marking a departure from "a great deal of poorly designed Victorian type" (p. 60). Once printing technologies allowed for more complex and arresting images, art directors were incorporated into agencies to help procure the right visuals for the agency's clients (Fox 1997). These individuals, more often coming from backgrounds in the arts than in business, argued that the "look" of an advertisement was as important as its written message (ibid., p. 40). As this suggests, these changes in the organizational structure of advertising agencies fostered another narrative framing, in which the advertisements themselves - especially their aesthetic beauty and potential for broad impact become moral objects for advertising agents.

The thesis of Luke Sullivan's (2003) Hey Whipple, Squeeze This, echoes this narrative as it insists that advertising should strive to be interesting and engaging in the pursuit of sales, rather than being obnoxious and grating. Though the latter may drive sales equally well, Sullivan compares this to performing a disgusting behavior, asking "would you also spit on the table to 
get my attention? It would work, but would you" (pp. 3-4)? ${ }^{13}$ In pursuing the path of creativity and trying to develop aesthetically pleasing advertisements, Sullivan argues an advertising practitioner can create "enduring brands and market leadership_-but gets there without costing anybody their dignity. You won't have to apologize to the neighbors for creating that irritating interruption to their sitcom last night" (p. 14).

As this example suggests, the creative-driven narrative frames advertising practitioners as trying to create interesting, inspiring, beautiful, emotional - in a word, meaningful advertisements. Advertising is taken as an art form, and the good practitioner is one who is passionate about making something worthwhile to a broad, imagined audience (such as "the neighbors") instead of producing "garbage," “crap," or "wallpaper" - advertisements that practitioners considered ugly, annoying, or insignificant. "There's so much throwaway crap in advertising," bemoaned one producer at CultureShock during a presentation. Rather than "crap" advertisements, in this frame advertising professionals are trying to create art. By creating art, this narrative posits, advertising professionals enrich the public's cultural life in a meaningful way, thereby using their creativity for the betterment of society.

Copywriter $(A \& S)$ : I fell in love with advertising because of the eight and a half by eleven ${ }^{14}$, flipping through the award annuals and like, 'that is freaking cool.' ... You know basically you're taking a ... sheet of paper that's blank and you create something. Each thing is almost kind of like a work of art, and it's called 'commercial art,' for sure. It's commissioned, but ... you're

${ }^{13}$ Spitting on a table is a reference to the 1947 film The Hucksters, in which a client spits on a table to make a point about how his disgusting act, like annoying and repetitive advertising, is nonetheless memorable and therefore effective. Fox (1997, pp. 201-202) suggests the book on which this film is based significantly influenced public perception of the advertising industry. $148.5 " * 11 "$ is the American standard size of a piece of paper. 
still trying to put something out there that speaks to people and it's just plain cool. I try to for the most part do things that I think are cool.

In this narrative, the client all but vanishes from the justification and instead caring lies in giving meaningful work to a generic audience. Rather than forcing unwanted advertisements on individuals, practitioners depict it as gift-giving relationship (cf. Mauss 2002; Zelizer 2010).

Art Director Intern (CS): What you're doing is making gifts for people, like, how do you enrich someone's life? ... So advertising needs to shift from 'what's the best ROI [return on investment] for the brand and how can we cut cost on printing' to 'how can we make gifts for people,' because there's too much noise out there.

ACC: "Noise," meaning?

Art Director Intern (CS): Just like - I have installed ad blocker on my computer and I work in advertising. There's too much.

$A C C$ : So then what makes a good advertisement?

Art Director Intern (CS): It's not an advertisement. A good advertisement is not an advertisement, it's a gift.

The abundance of bad, poorly-made, annoying advertising is interpreted as the product of other, immoral marketers, typically those who are untrained or simply untalented and just seeking to make money without being qualified for the job. "You can just tell [when] somebody is just not good at design and, you know, they were hired to create an ad or wedding invitation or a newspaper ad or something like that, and it's just poorly designed - it just it makes me cringe," explained a senior art director at Alexander \& Sons.

Art Director $(A \& S)$ : That's something about advertising I hate the most: just how anybody with a computer or PhotoShop is now, you know, a 'designer,' or can be hired and just do ads for 
companies, you know? So it just kind of takes that special skill that designers have, just takes that away from them.

On the other hand, good advertising done by passionate practitioners makes for a better world. Copywriter (CS): Doing good work ... makes the world so much more bearable to live in.... Like, people love commercials during the Super Bowl ... Imagine if that was all time! If all spots were funny and all of them were like dramatic and heartfelt and earnest. It makes people feel something, and that's what they want to do - people want to feel, be entertained or add value to someone's live, that's all we want. And good work helps do that, it makes people laugh, it could make them think about something, make them reconnect with someone else and makes them get off the couch and start running, makes them eat healthier. It just makes them act in certain ways that maybe is better to their lives ...

In the creative-driven narrative, "creativity" needs to be protected from clients. Clients, according to some of the practitioners, do not always understand or appreciate creative and innovative ideas. When clients reject ideas the creatives view as good, the creatives become frustrated - not because the client is rejecting the advertiser's help, but because the client is rejecting the advertiser's meaningful work.

An account executive and a designer at Pioneer are talking back and forth at the designer's desk, discussing feedback from a client. The designer is frustrated, saying the client uses words that sound smart without knowing what they mean, that the client's approach is "retarded." The account executive notes that the designer is "fuming! You're turning the color of your shirt... so, a light orange." This joke seems to calm down the designer a bit, and the two continue discussing what needs to happen with the client's project.

After the account executive leaves, the designer says out loud to the room where creative 
services sits, "Want to see what [the client] is so opposed to?" Another designer says 'yeah,' and she and two other creatives gather behind the designer's chair as he explains the project. One creative asks why the client wants these changes right now; the designer says it's because the client is "panicking." The creative director says: "Well, it still looks good. You kept it looking good through all this bullshit." [Field note excerpt]

Creative Director $(C S)$ : I wish I could just change the intelligence of some of the clients about creativity and what not. And again, it's art. And I wish it was just, I wish - Yeah! I wish people understood art, damn it! [laughs]

The frustrations that arise in this narrative framing can have economic consequences for the agency. Creatives at all three agencies cited opportunities to do better work as a key factor for leaving one agency and moving to another, in some cases taking pay cuts for such opportunities. Likewise, creatives recalled turning down better-paying jobs at other agencies because they viewed those agencies and their poorer quality of work as unacceptable.

Executive Creative Director (CS): I can't imagine working somewhere and someone says someone in one way or another says it's okay that this isn't very creative, [that] this doesn't look very good ... you know? I can't imagine that, I can't imagine that at all. I guess you will just be coming to work doing something that someone is asking you to do basically... you will be a machine... 
As the sources of the quotes here suggest, this frame was most commonly brought up by those in creative services, who are responsible for thinking up, designing, and producing the actual advertisements and campaigns. ${ }^{15}$ Yet other departments also encouraged this perspective:

CultureShock's account services department has gathered in the agency's largest meeting room, where the head of account services is giving a presentation on how the job should be done. The head of account services reads another slide from his presentation, which is projected up on a screen at the head of the room: "You and the agency are judged by the quality and quantity of ideas produced under your watch. It's not about getting through meetings with a 'good job' and 'thanks' from clients. A year's worth of great meetings and well-written contact reports means nothing if you have no produced work to show for it." He warns that with bigger clients, this can easily happen, so 'keep score on stuff you work on,' because not making good work isn't okay.

[Field note excerpt]

The creative-driven narrative, like the account-driven narrative, also makes it possible for advertisers to justify working for a morally reprehensible client by focusing on making quality advertisements. The agency with the tobacco client is again illustrative: "Did I want to work on tobacco? No," said one account services person who had formerly worked for a hospital. While he did not join the agency to work on that account, it had been added to his workload over time. He said he has become comfortable with the account, because some of the "best work" the agency does is for the tobacco client. "The work for them is good, even though working for them is not," he explained. Similarly, a creative described how, even though no one "is super excited

${ }^{15}$ Some advertising practitioners, especially in the creative department, also linked producing good work to the fulfilment of their personal passions irrespective of broader imagined audiences. However, this article does not seek map every single narrative offered, but rather to demonstrate that narratives about contributing to the common good (such as through art) are salient within the advertising industry. 
to work on" the tobacco account because of ethical issues, "they're our coolest clients. ... they want to do something cool. They want to have their brand stand for something and they're fun to work with, so even though it's tobacco ... it's fun, you can do stuff for them." Because the client wanted their brand to "stand for something," this gave the creative team opportunities to try to produce more thoughtful, evocative work. ${ }^{16}$ Even though the employees of this agency recognize the moral stigma of working for a tobacco client, they make sense of the situation as an opportunity to create "cool," "fun" ads - in other words, work that is meaningful for a broader imagined audience.

\section{Strategic-driven: care through meaningful connections}

The third major narrative we identified is that strategic-driven narrative, in which agents just their moral worth by framing their work as helping specific groups of consumers. Historically, the legitimization of advertising practice has typically rested on the industry's efforts to create knowledge about consumers and their corresponding claims of esoteric knowledge in manipulating consumer behavior (Mazzarella 2003, p. 234; Navon 2017). While this legitimacy was achieved through various networks of expertise since 1920s (Eyal 2013; Navon 2017), consumer research activities were kept at a distance from the process creating advertisements; research was either handled by agency departments that had limited interaction or influence on the departments that developed the advertising, or handled by other market research firms altogether (Sivulka 2012; Tungate 2007). However, this network of expertise began to shift in

\footnotetext{
16 The counter-example to this case was a pharmaceutical client at the same agency, which the creatives would sometimes complain about: while the client was viewed as providing a helpful product, rather than a harmful one, the creative team often griped about not having as much leeway to produce 'creative' work because of a more difficult, restrictive client.
} 
the 1960s: large advertisers began producing their own research, and agency research departments began breaking away to form independent firms at the same time as market research techniques were improving (Tungate 2007, p. 89). In response to this shift, Stanley Pollitt of the British advertising agency Boase Massimi Pollitt established a new role, the account planner: a "trained researcher," meant to have "equal status as a working partner" alongside the account executive and the creative director, and who would be involved "more closely in the development of creative ideas" by bringing in a researched understanding of the consumer to the process (Tungate 2007, p. 90).

In the United States, the practice of account planning was adopted in the 1980s by several west coast agencies, including Chiat/Day (which created the iconic "1984" commercial for Apple), Wieden and Kennedy (which introduced "Just Do It" for Nike), and Goodby, Silverstein \& Partners (which developed the famous “got milk?” campaign) (Steel 1998; Tungate 2007). Following account planning's association with the success of those agencies, the practice spread throughout the country (Steel 1998). Account planners are intended to develop an "in-depth understanding of consumers," including by generating "insights" about specific groups of consumers' consumption habits (Tungate 2007, p. 89; see also Ariztia 2015). The incorporation of account planning and its corresponding changes in the organizational structure of advertising agencies fostered a third narrative framing, in which consumers are the moral object for advertising agents.

Jon Steel (1998) articulates this narrative in his informative and instructive Truth, Lies, and Advertising: The Art of Account Planning, arguing that

A new model for advertising is necessary that is based on the understanding that consumers are people and recognizes that people are inherently complex, emotional, unpredictable creatures, 
whose relationships with each other and with the "things" (including brands, products, and advertising) around them are more important than the "things" themselves (p. 23, emphasis in original).

As this excerpt from Steel suggests, in this narrative the ideal is to provide a meaningful relationship to the customer. This frame casts the advertising practitioner as still caring, but for a consuming public rather than a paying client (as in the account-driven narrative):

President $(A \& S)$ : I get to come to work every day and help consumers find products and services that will make their lives better. That is what it really comes down to, right? So whether it's a new insurance company or it's a new brand of soda-pop or whatever it is that they haven't discovered before that makes their life more enjoyable or better in some way; that is really what we do, and that is pretty cool to me. I think that that's not a bad thing...

In this framing, practitioners are moral through their empathy for the consuming audience, instead of being self-centered on serving clients or making creative commercials for creativity's sake. Practitioners should have more "respect and understanding of their audience," as a senior strategist at Pioneer put it:

Senior strategist (PI): We always need to take a step back. Take your marketer hat off, and be like, 'how do you like to get information from brands,' you know? What's your experience? How do you want to be treated as a customer, you know? ... you look at someone in marketing-speak or whatever, you're talking about 'the consumer,' right? But, it's like - thinking of them as people, you know? And we're all people, and we all are consumers in one way, shape, or form.

The practitioners who draw on this narrative assert a moral identity by empathizing with the consumer, actively avoiding belittling them. "Evil, to me, is people that make a lot of work [advertisements] that drastically undervalue how smart people are," explained a senior creative 
director from CultureShock.

Empathizing with consumers requires understanding what is important to them - a duty typically assigned to the account planner - so that the advertisements made are not "annoying," but instead meaningful.

Junior Account Planner (CS): I describe [my job] as: I am the representative of the consumer within the work, $[\ldots]$ making sure that the relationship between the consumer and the brand isn't a frivolous one or a fleeting one, finding insights about the consumer.... And figuring out what purpose that service or product or brand can have in their lives, that it isn't serving now.

By positioning their work as beneficial for a consuming audience, practitioners can defend their moral identities against the stigma of their profession. "I think that's really what product advertising's purpose is, is to help a user [consumer] make a connection to a brand, feel good about buying that brand," explained a developer from Alexander \& Sons. "And I'm not talking like, 'this brand makes me feel all warm and fuzzy!' I'm talking about like, I have a little bit of 'hey, I made a good choice,' you know?'

The strategic-driven narrative sometimes sounds somewhat similar to the creative-driven; like the creative-driven narrative, advertising practitioners are moral because the work they do is meaningful to audiences. However, the creative-driven narrative has its criticisms for the strategic-driven narratives. Creatives have long criticized research as stifling to creativity (Tungate 2007), and a few creatives in our sample sometimes criticized strategic-driven narratives for what they saw as a dishonest "pandering:"

Senior Art Director $(A \& S)$ : For me, advertisements that pander, that sort of play the obvious like, I look around, 'is this working on other people?' And you see like other people like, 
[imitating an unintelligent voice] 'yeah, that commercial's really funny.' It's like, no, that wasn't funny, it was stupid and terrible!' You know? It's pandering, and you don't even realize it's happening to you.

But according to the strategic-driven narrative, practitioners too attached to the creative-driven narrative can be wont to value "creativity" over a meaningful relationship with specific audiences. By understanding the particular audience - through "insights" and "human truths" practitioners avoid making ads that are "superficial and silly," "not grounded in anything."

Junior Account Planner (CS): we would see much - so much more thoughtful executions of advertising, if there were more people understanding [the consumer]. Geez, okay what, we have this product; why does that matter to people? They are not answering that question: why does that matter what you are telling to them?

"Sometimes [advertisements are made] just for the creatives themselves," grumbled a senior account planner at Alexander \& Sons, who felt advertisements should truly be made "for the target [audience]."

Likewise, the strategic-driven narrative values the public audience over the client. The senior account planner at Alexander \& Sons continued to say too made advertisements are made "for the client, I think, other than the ones that are for the creative's reel [portfolio]." A copywriter at the same agency agreed:

Copywriter $(A \& S)$ : I think a lot of [advertisements] are made for clients, sadly. They shouldn't be! Nike is made for the consumer. Nike ads are made for the consumer, you know? They have a shot of a fat kid running for 30 seconds, and everyone explodes, because they're like 'I know that, I get it, I've been there, I hated getting up at 5:00AM and running, but I've been there.' 
Examples such as these illustrate how the strategic-narrative differs from both the account-driven narrative and the creative-driven narrative while still being based on caring for others.

The most obvious economic implication of the strategic-driven framing is that it justifies the existence of the account planner in the advertising agency. Account planning is a relatively new discipline, emerging in the United Kingdom in the mid-1960s and spreading to the United States in the early 1980s (Steel 1998; Tungate 2007). The chairman at CultureShock, when asked what campaign he was proudest of, said it was an extremely effective public service campaign, the strategy for which "convinced me that [account planners] should be paid." "If any of us ever go to heaven," the chairman said, "it'll be because of that campaign."

Like the account- and creative-driven narratives, the strategic-driven narrative was also used to justify working on the tobacco client at one of the agencies. By framing working for the tobacco client as a question of understanding the intended consumer and respecting who they are - and who they are not - the practitioners could present moral identities in spite of working for a stigmatized client:

Creative Services: Small background: my mom was a nurse and my stepdad is an oncologist, so [I've been] exposed for a very long time to the sort of hazards, danger and tragedy of, you know, tobacco addiction, essentially. So I'm about as much of a non-smoker as you can possibly find. [...] And, you know, the guys we market to are 25 to, let's say 60 , like these guys - these are like some of the least marketable guys that you can - well not marketable themselves but hardest to market to. They just don't, they're not trendy, they don't give a shit, and they're going to do it no matter what. And so you know that's their vice; like I'll drink beer, they [use tobacco]. They're set in their ways. [...] So you know to those guys, to like mature adults who are making their own decisions, that's fine. If we came anywhere close to marketing to children, I would morally have a problem with it - and fortunately we don't. 
Account Planning: I mean I am against [selling tobacco] of course, but you cannot change the mind of the people that are doing it. ... I think if you are just like a regular person that likes [tobacco] or whatever then it's [your] choice, so you deserve advertising or something. Like yeah, there is something that people can do for you to show you what's the better quality or the most economic thing, the cheapest one.

Practitioners from all three agencies used this type of logic, particularly for other clients whose products they didn't believe in or personally support. 'So, [Packaged Food Client] - I don't buy their stuff because I think it would kill you," explained a copywriter at CultureShock. However,

Copywriter $(C S)$ : ... while I may not be a fan of it, there are thousands, millions of families out there who love the product and it means so much to them and it's just who they are and how dare I judge the way they live? I let them do whatever they want to do and if whatever I write or create makes them [buy] more of it to make them feel happy? Sure. That makes me feel okay.

By citing a particular audience, practitioners employing strategic-driven narratives can defend their moral identities against the stigma of their industry by framing themselves as helping that audience - as well as by presenting that particular audience as not vulnerable or harmed, compared to other audiences that might be harmed by the practitioner's work.

\section{DISCUSSION}

This article suggested that structured, collectively-held narratives allow professionals to link their work - through moral objects - to broader notions of a common good, and to thereby depict their professional community as abiding by clear moral codes. For a community that recognizes itself as morally stigmatized, such stories about how and why their work is good work 
are crucial for moral impression management. In other words, while the fact that these advertising professionals morally justify themselves is to be expected (Goffman 1959), this article advances our understanding of these justifications, illustrating that they have specific, patterned narrative structures that tie together particular conceptions of the self, work, and the common good in ways that are rooted in the sociotechnical history of their industry. Indeed, the article outlined three key narratives advertising professionals use in thinking about the moral value of their work and its relation to various conceptions of the social good. In account-driven narratives, which focus on the client, advertising professionals primarily used the logic that advertising helps society by promoting good products and helping their clients. In creativedriven narratives, which were more focused on the advertisements themselves, the logic that good advertising helps the community by bringing emotion and inspiration into public life dominated. Strategic-driven narratives, which focus on relationships with consumers, used a different logic that placed helping consumers and spreading civic values at the fore. Thus, clients, advertisements, and consumers served as the moral objects that anchor the narratives professionals proffered.

The article highlights the role of imagined objects of moral care in construing broader notions of self-worth. Moral objects such as the ones advertising professionals invoke figure strongly in other sites as well. For example, Kristin Luker (1984) has shown the decisive role of the fetus and the attributes pro-choice and pro-life activists assign to it in making broader arguments about the morality or immorality of abortion. In a very different way, Bruno Latour (2005) has demonstrated that objects - even trivial ones like street-signs and roads - orient us toward abstract moral codes (pp. 77-78). Gabriel Abend (2014), as well as Boltanski and Thévenot (2006), identify objects as bearing a decisive role in indicating and helping adjudicate 
between different moral frameworks. By tracing how individuals use moral objects to help present a narrative relationship between their day-to-day endeavors and generalized notions of morality, this article demonstrates the mechanics of moral objects in managing self-worth. The narratives professionals proffer in the workplace are not only related to workers' satisfaction; they also affect the broader decisions organizations make and the policies they instate. Indeed, economic sociologists have shown time and again how questions of right and wrong as well as the narratives that articulate them shape economic and financial decision making (Wherry 2016, 2012; Zelizer 1979, 2010; see also Wuthnow 1996). Thus, ways of framing moral questions are central to policy making and, as such, are central to workplace interactions and professional community processes (see also Brophy 2014; Dobbin 1994). While our research - being an interview- and ethnography-based study - does not seek to make causal claims about the degree to which these professionals' stated positions directly affect their actions, it demonstrates that concerns about morality, questions of benefitting others through advertising work, and conundrums about the ethical course of action greatly inform advertising agencies' industrial culture.

Understanding how professional groups respond to perceived challenges to their selfworth is important for understanding more general communal responses to moral stigma. Recent work in cultural sociology has been interested in how members of communities that suffer from discrimination or economic disadvantage perceive differences between themselves and other groups (Fleming, Lamont, and Welburn 2012; Lamont 1992; Lamont et al. 2016; Mizrachi and Herzog 2013; Silva 2012). These studies have shown that community members will often respond to a perceived social devaluation by adopting alternative ways of evaluating themselves, which they use in order to represent their group as superior to others (Lamont 2000). However, 
such studies have tended to focus on disadvantaged groups defined by ethnic, racial, or economic characteristics, where professional communities are different in that membership in them is voluntary. Examining how other types of communities develop narratives and identify objects that link them to a specific notion of the common good can shed new light on how groups grapple with stigmatization.

Future studies in this area can help bridge between cultural sociological approaches to morality and other sociological subfields, especially social psychology. Social psychologists have demonstrated that individuals care deeply about being perceived as moral persons, in the sense of being fair, of caring for others, and of respecting social norms and hierarchies, even when their behavior in situ differs from their expressed moral standard (Baston et al. 1999; Franzen and Pointner 2012). Social psychologists often incorporate the effects of "culture" broadly defined - into their models, with social psychologists Stets and Carter (2012) suggesting, for example, that "individuals likely draw on shared symbols and definitions derived from culture to identify the degree to which situations contain moral meanings" (p. 126, our emphasis; Burke and Stets 2009). Examining in detail how individuals identify situations where moral justification is called for and what cultural strategies they employ can help social psychologists specify why actors find some meanings particularly relevant to their moral self and how they employ them to generate confirmation of their identity. Similarly, such research can help cultural sociologists specify the mechanism that causes actors to seek out cultural narratives that provide evidence in support of their moral stature and help them counteract negative feedback.

Some of the limitations of this study also identify possibilities for future research. Whereas this study looked only at advertising agencies, future research may expand to other professions and compare the extent to which a profession is stigmatized in society to the types of 
justification and moral reasoning one might find within that professional community. Certain types of occupations are certainly more polluted than others, and this may certainly affect the extent to which workers may employ narratives to fend off stigmatization. Advertising, although stigmatized, has professional middle-class status and garners relatively high earnings and cultural capital. Occupations such as janitors or sewage workers are likely to have fewer symbolic resources to perform the identity management work described in this article (see Davis 1984). Comparative research in this area would contribute to our understanding of different extents to which certain occupations are symbolically polluted. In this, future research may also compare similar industries cross-nationally, and thereby shed light on the cultural specificity of repertoires of moral narratives. Finally, future research may also explore variations in how and when members of professional communities find moral narratives to be felicitous. If moral worth is important to job satisfaction, it is possible that professionals who do not use or believe such narratives are more likely to leave their jobs in search of other work.

The understanding that admen and adwomen are invested in specific notions of the social good and of their contribution to it complicates one of the longest-standing storylines in the sociology of culture, according to which the culture industry stands in contradistinction to civil values and caring interpersonal relations (Adorno and Horkheimer 1979; Ewen 2001; Packard [1957] 2007; cf. Schudson 1981). While creative industries are, to some extent, implicated in exploitative social structures, the individuals who populate this industry are often aware of and troubled by the negative side of their profession, and seek ways to reconcile their work with abstract notions of the common good. Therefore, efforts to criticize and challenge those exploitative macro-level structures should take into consideration the micro-level deployment of narrative logics used to justify the work of the individuals who constitute that system. 


\section{ACKNOWLEDGEMENTS}

We thank the many employees of the three agencies in this study, who generously donated their

time and thoughts. We would also like to thank Jeffrey Alexander, Matt Andersson, Sorcha

Brophy, Gary Allen Fine, Thomas Lyttleton, Candas Pinar, Samuel Stabler, and Frederick

Wherry, all of whom provided insightful suggestions and feedback that improved this article. We

also thank the anonymous reviewers and one of the senior editors at Theory \& Society, whose

reviews likewise strengthened this article.

\section{REFERENCES}

Abbott, A. (1988). The system of professions: An essay on the division of expert labor. Chicago: University of Chicago Press.

Abend, G. (2014). The moral background: An inquiry into the history of business ethics. Princeton: Princeton University Press.

Adorno, T. W., \& Horkheimer, M. (1979). Dialectic of enlightenment. London: Verso.

Alexander, J. C., \& Smith, P. (2003). The strong program in cultural sociology: Elements of a structural hermeneutics. In The meanings of social life: A cultural sociology (pp. 11-26). Oxford: Oxford University Press.

Alvesson, M. (1998). Gender relations and identity at work: A case study of masculinities and femininities in an advertising agency. Human Relations, 51(8), 969-1005.

Anteby, M. (2010). Markets, morals, and practices of trade: Jurisdictional disputes in the US commerce in cadavers. Administrative Science Quarterly, 55(4), 606-638.

Ashforth, B. E., \& Reingen, P. H. (2014). Functions of dysfunction: Managing the dynamics of an organizational duality in a natural food cooperative. Administrative Science Quarterly, 59(3), 474-516.

Bartmanski, D., \& Woodward, I. (2015). Vinyl: The analogue record in the digital age. New York: Bloomsbury Publishing.

Batson, C. D., Thompson, E. R., Seuferling, G., Whitney, H., \& Strongman, J. A. (1999). Moral hypocrisy: appearing moral to oneself without being so. Journal of Personality and Social Psychology, 77(3), 525.

Becker, H. S. (2008). Art Worlds. Los Angeles: University of California Press.

Besharov, M. L. (2014). The relational ecology of identification: How organizational identification emerges when individuals hold divergent values. Academy of Management Journal, 57(5), 1485-1512.

Bielby, D. D., \& Bielby, W. T. (1996). Women and men in film: Gender inequality among writers in a culture industry. Gender \& Society, 10(3), 248-270.

Bielby, D. D., \& Bielby, W. T. (2002). Hollywood dreams, harsh realities: writing for film and television. Contexts, 1(4), 21-27.

Blau, J. R. (1992). The shape of culture: A study of contemporary cultural patterns in the United States. New York: Cambridge University Press. 
Boltanski, L., \& Thévenot, L. (1999). The sociology of critical capacity. European journal of social theory, 2(3), 359-377.

Boltanski, L., \& Thévenot, L. (2006). On justification: Economies of worth. Princeton: Princeton University Press.

Bourdieu, P. (1993). The field of cultural production. New York: Columbia University Press

Bourdieu, P. (1996). The Rules of art: Genesis and structure of the literary field. Stanford: Stanford University Press.

Brophy, S. A. (2014). Making morals: Standard-setting in organizations. In V. Jeffries (ed.) The Palgrave handbook of altruism, morality, and social solidarity (pp. 353-366). New York: Palgrave Macmillan.

Burke, P. J., \& Stets, J. E. (2009). Identity theory. New York: Oxford University Press.

Campbell, J. L. (2006). Institutional analysis and the paradox of corporate social responsibility. American Behavioral Scientist, 49(7), 925-938.

Campbell, J. L. (2007). Why would corporations behave in socially responsible ways? An institutional theory of corporate social responsibility. Academy of management Review, 32(3), 946-967.

Cardona, M. (2001). Ad pros rank low in honesty and ethics." Ad Age, December 11. http://adage.com/article/news/ad-pros-rank-low-honesty-ethics/33412/. Accessed 26 December 2015.

Cohen, A. C. (2016). Advertising Age. In F. F. Wherry \& J. Schor (eds.) The SAGE encyclopedia of economics and society (pp. 44-47). Thousand Oaks: SAGE.

Creed, W. D., DeJordy, R., \& Lok, J. (2010). Being the change: Resolving institutional contradiction through identity work. Academy of management journal, 53(6), 1336-1364.

Davis, D. S. (1984). Good people doing dirty work: A study of social isolation. Symbolic Interaction, 7(2), 233-247.

Dobbin, F. (1994). Forging industrial policy: The United States, Britain, and France in the railway age. Cambridge University Press.

Dowd, T. J., \& Blyler, M. (2002). Charting race: the success of black performers in the mainstream recording market, 1940 to 1990. Poetics, 30(1-2), 87-110.

Dromi, S. M. (2012). Penny for your thoughts: Beggars and the exercise of morality in daily life. Sociological Forum 27(4), 847-871.

Dromi, S. M. (2014). Uneasy Settlements: Reparation Politics and the Meanings of Money in the Israeli Withdrawal from Gaza. Sociological Inquiry, 84(2), 294-315.

Dromi, S. M., \& Illouz, E. (2010). Recovering morality: Pragmatic sociology and literary studies. New Literary History, 41(2), 351-369.

Dru, J. M. (1996). Disruption: Overturning conventions and shaking up the marketplace New York: Wiley.

Ewen, S. (2001). Captains of consciousness: Advertising and the social roots of the consumer culture. New York: Basic Books.

Eyal, G. (2013). For a sociology of expertise: The social origins of the autism epidemic. American Journal of Sociology, 118(4), 863-907.

Fenwick, R., \& Tausig, M. (1994). The macroeconomic context of job stress. Journal of health and social behavior, 35(3), 266-282.

Fleming, C. M., Lamont, M., \& Welburn, J. S. (2012). African Americans respond to stigmatization: the meanings and salience of confronting, deflecting conflict, educating the ignorant and 'managing the self'. Ethnic and Racial Studies, 35(3), 400-417. 
Fox, S. (1997). The mirror makers: A history of American advertising and its creators. Chicago: University of Illinois Press.

Franzen, A., \& Pointner, S. (2012). Anonymity in the dictator game revisited. Journal of Economic Behavior \& Organization, 81(1), 74-81.

Gallup Inc. (2015). Honesty/Ethics in Professions. Gallup, 06 December. http://www.gallup.com/poll/1654/honesty-ethics-professions.aspx. Accessed 26 December 2015.

Gehman, J., Trevino, L. K., \& Garud, R. (2013). Values work: A process study of the emergence and performance of organizational values practices. Academy of Management Journal, 56(1), 84-112.

Glanville, J. L., Paxton, P., \& Wang, Y. (2016). Social capital and generosity: A multilevel analysis. Nonprofit and Voluntary Sector Quarterly, 45(3), 526-547.

Goffman, E. (1959). The presentation of self in everyday life. New York: Doubleday.

Goffman, E. (1976). Gender advertisements. New York: Harper.

Goldman, R. (1992). Reading ads socially. London: Routlege.

Goodrum, C., \& Dalrymple, H. (1990). Advertising in America: The first two hundred years. New York: Harry N. Abrams, Inc.

Gorski, P. S. (2013). Bourdieusian theory and historical analysis: Maps, mechanisms, and methods. In P. S. Gorski (ed.). Bourdieu and historical analysis (pp. 327-266). Durham: Duke University Press.

Graham, J., Haidt, J., \& Nosek, B. A. (2009). Liberals and conservatives rely on different sets of moral foundations. Journal of Personality and Social Psychology, 96(5), 1029-1046.

Grossberg, L., Nelson, C., \& Treichler, P. (eds.). (1991). Cultural studies. New York: Routledge. Haidt, J., \& Graham, J. (2009). Planet of the Durkheimians, where community, authority, and sacredness are foundations of morality. In J. T. Jost, A. C. Kay, \& H. Thorisdottir (eds.), Social and psychological Bases of Ideology and System Justification (pp. 371-401). New York: Oxford.

Healy, K., \& Krawiec, K. D. (2012). Custom, contract, and kidney exchange. Duke Law Journal 62, 645-670.

Heimer, C. A., \& Staffen, L. R. (1998). For the sake of the children: The social organization of responsibility in the hospital and the home. Chicago: University of Chicago Press.

Hitlin, S., \& Andersson, M. A. (2015). Dignity as moral motivation: The problem of social order writ small. In E. Lawler, S. Thye, \& J. Yoon (eds.). Order on the edge of chaos: Social psychology and the problem of social order (268-285). Cambridge: Cambridge University Press.

Hitlin, S., \& Vaisey, S. (2013). The new sociology of morality. Annual Review of Sociology, 39, 51-68.

Ho, K. (2009). Liquidated: An ethnography of Wall Street. Durham: Duke University Press.

Illouz, E. (1997). Consuming the romantic utopia: Love and the cultural contradictions of capitalism. Berkley: University of California Press.

Illouz, E. (2014). Hard-core romance: "Fifty Shades of Grey," best-sellers, and society. Chicago: University of Chicago Press.

Jackall, R. (2010). Moral mazes: The world of corporate managers. New York: Oxford University Press. 
Johnson, B. (2015). State of the Agency Market: What You Need to Know. Ad Age, 26 April. http://adage.com/article/digital/datacenter-agency-report-2015-charts/298214/. Accessed 6 May 2016.

Judge, T. A., Bono, J. E., \& Locke, E. A. (2000). Personality and job satisfaction: The mediating role of job characteristics. Journal of Applied Psychology, 85(2), 237.

Judge, T. A., Heller, D., \& Mount, M. K. (2002). Five-factor model of personality and job satisfaction: A meta-analysis. Journal of Applied Psychology 87(3), 530-541.

Judge, T. A., Thoresen, C. J., Bono, J. E., \& Patton, G. K. (2001). The job satisfaction-job performance relationship: A qualitative and quantitative review. Psychological Bulletin 127(3), 376-407.

Klett, J. (2014). Sound on Sound: Situating Interaction in Sonic Object Settings. Sociological Theory, 32(2), 147-161.

Klett, J., \& Gerber, A. (2014). The meaning of indeterminacy: Noise music as performance. Cultural Sociology, 8(3), 275-290.

Kohn, M. L., \& Schooler, C. (1982). Job conditions and personality: A longitudinal assessment of their reciprocal effects. American journal of Sociology, 87(6), 1257-1286.

Koppman, S. (2014). Making art work: Creative assessment as boundary work. Poetics, 46, 1-21. Lamont, M. (1992). Money, morals, and manners: The culture of the French and the American upper-middle class. Chicago: University of Chicago Press.

Lamont, M. (2000). The dignity of working men: Morality and the boundaries of race, class, and immigration. Cambridge: Harvard University Press.

Lamont, M., Schmalzbauer, J., Waller, M., \& Weber, D. (1996). Cultural and moral boundaries in the United States: Structural position, geographic location, and lifestyle explanations. Poetics, 24(1), 31-56.

Lamont, M., Silva, G. M., Welburn, J., Guetzkow, J., Mizrachi, N., Herzog, H., \& Reis, E. (2016). Getting respect: Responding to stigma and discrimination in the United States, Brazil, and Israel. Princeton University Press.

Latour, B. (2005). Reassembling the social: An introduction to actor-network-theory. Oxford and New York: Oxford University Press.

Luker, K. (1984). Abortion and the politics of motherhood. Berkeley: University of California Press.

Malefyt, T. D., \& Moeran, B. (eds.). (2003). Advertising cultures. New York: Berg.

Marcuse, H. (1964). One-dimensional man: Studies in the ideology of advanced industrial society. New York: Routledge.

Mauss, M. (2002). The gift: The form and reason for exchange in archaic societies. New York: Routledge.

Mazzarella, W. (2003). Shoveling smoke: Advertising and globalization in contemporary India. Durham: Duke University Press.

McCormick, L. (2009). Higher, faster, louder: Representations of the international music competition. Cultural Sociology, 3(1), 5-30.

McDonough, J., \& Egolf, K. (Eds.). (2015). Representations of advertising in motion pictures, television, and literature. In The Advertising Age encyclopedia of advertising (pp. 1083-7). New York: Routledge.

McLeod, C., O'Donohoe, S., \& Townley, B. (2009). The elephant in the room? Class and creative careers in British advertising agencies. Human Relations, 62(7), 1011-1039. 
Mears, A. (2011). Pricing beauty: The making of a fashion model. Berkley: University of California Press.

Miller, D. (1998). A theory of shopping. Cambridge: Polity Press.

Mizrachi, N., \& Herzog, H. (2012). Participatory destigmatization strategies among Palestinian citizens, Ethiopian Jews and Mizrahi Jews in Israel. Ethnic and Racial Studies, 35(3), 418435.

Moeran, B. (1996). A Japanese advertising agency: An anthropology of media and markets. Honolulu: University of Hawaii Press.

Navon, D. (2017). Truth in advertising: Rationalizing ads and knowing consumers in the early twentieth-century United States. Theory and Society, 46(2), 143-176.

Neff, J. (2010). Ad industry battles back against bad rep, forms ethics institute." Ad Age, 7 June. http://adage.com/article/news/ad-industry-battles-back-bad-reputation/144288/. Accessed 26 December 2015.

Nelson, C., \& Grossberg, L. (Eds.). (1988). Marxism and the interpretation of culture. Chicago: University of Illinois Press.

O'Barr, W. M. (1994). Culture and the ad: Exploring otherness in the world of advertising. Boulder: Westview Press.

O’Boyle, N. (2012). Managing Indeterminacy: Culture, Irishness and the Advertising Industry. Cultural Sociology, 6(3), 351-366.

Ogilvy, D. ([1963] 2011). Confessions of an advertising man. London: Southbank Publishing.

Owles, E. (2017). The Making of Martin Shkreli as 'Pharma Bro'. The New York Times, 22 June. https://www.nytimes.com/2017/06/22/business/dealbook/martin-shkreli-pharma-bro-drugprices.html. Accessed 22 October 2017.

Packard, V. ([1957] 2007). The hidden persuaders. New York: Ig Publishing.

Peterson, R. A., \& Anand, N. (2004). The production of culture perspective. Annual Review of Sociology, 30, 311-334.

Pugh, A. J. (2013). What good are interviews for thinking about culture? Demystifying interpretive analysis. American Journal of Cultural Sociology, 1(1), 42-68.

Quinn, S. (2008). The transformation of morals in markets: Death, benefits, and the exchange of life insurance policies. American Journal of Sociology, 114(3), 738-780.

Ricoeur, P. (1967). The symbolism of evil. Boston: Beacon Press.

Ricoeur, P. (1970). Freud and philosophy. New Haven: Yale University Press.

Riessman, C. K. (1994). Narrative analysis. Newbury Park: SAGE.

Rivera, L. A. (2012). Hiring as cultural matching: The case of elite professional service firms. American Sociological Review, 77(6), 999-1022.

Rupp, D. E., Ganapathi, J., Aguilera, R. V., \& Williams, C. A. (2006). Employee reactions to corporate social responsibility: An organizational justice framework. Journal of Organizational Behavior, 27(4), 537-543.

Schieman, S., Whitestone, Y. K., \& Van Gundy, K. (2006). The nature of work and the stress of higher status. Journal of Health and Social Behavior, 47(3), 242-257

Schor, J. (2004). Born to buy: The commercialized child and the new consumer culture. New York: Simon and Schuster.

Schudson, M. (1981). Criticizing the critics of advertising: towards a sociological view of marketing. Media, Culture \& Society, 3(1), 3-12.

Schudson, M. (1984). Advertising, The uneasy persuasion: Its dubious impact on American society. New York: Basic Books. 
Silva, G. M. D. (2012). Folk conceptualizations of racism and antiracism in Brazil and South Africa. Ethnic and Racial Studies, 35(3), 506-522.

Sivulka, J. (2012). Soap, sex, and cigarettes: A cultural history of American advertising. (2 ${ }^{\text {nd }}$ ed.). Boston: Wadsworth, Cengage Learning.

Smith, P. (2010). Why war?: The cultural logic of Iraq, the Gulf War, and Suez. Chiago: University of Chicago Press.

Snyder, W. S. (2011). Principles and practices for advertising ethics. The Institute for Advertising Ethics.

http://www.aaf.org/_PDF/AAF\%20Website\%20Content/513_Ethics/IAE_Principles_Practic es.pdf. Accessed 18 October 2017.

Stark, D. (2009). The sense of dissonance: Accounts of worth in economic life. Princeton: Princeton University Press.

Statistic Brain. (2015). Advertising Agency Industry Statistics. Statistic Brain Research Institute. http://www.statisticbrain.com/advertising-agency-industry-statistics/. Accessed 6 May 2016.

Steel, J. (1998). Truth, lies, and advertising: The art of account planning. New York: Wiley.

Stets, J. E., \& Carter, M. J. (2012). A theory of the self for the sociology of morality. American Sociological Review, 77(1), 120-140.

Stets, J. E., \& Cast, A. D. (2007). Resources and identity verification from an identity theory perspective. Sociological Perspectives, 50(4), 517-543.

Sullivan, L. (2003). Hey, Whipple, squeeze this: A guide to creating great ads. Hoboken: John Wiley \& Sons, Inc.

Tungate, M. (2007). Adland: A global history of advertising. Philadelphia: Kogan Page.

Weiss, R. S. (1995). Learning from strangers: The art and method of qualitative interview studies. New York: Simon and Schuster.

Wherry, F. F. (2012). The culture of markets. Malden: Polity Press.

Wherry, F. F. (2016). Relational accounting: A cultural approach. American Journal of Cultural Sociology, 4(2), 131-156.

White, H. (1973). Metahistory: The historical imagination in nineteenth-century Europe. Baltimore: Johns Hopkins University Press.

Wilhelm, M. O., \& Bekkers, R. (2010). Helping behavior, dispositional empathic concern, and the principle of care. Social Psychology Quarterly, 73(1), 11-32.

Williamson, J. (2002). Decoding advertisements: Ideology and meaning in advertising. New York: Marion Boyars.

Wuthnow, R. (1996). Poor Richard's principle: Recovering the American dream through the moral dimension of work, business, and money. Princeton: Princeton University Press.

Zelizer, V. A. (1979). Morals and markets: The development of life insurance in the United States. New York: Columbia University Press.

Zelizer, V. A. (2010). Economic lives: How culture shapes the economy. Princeton: Princeton University Press. 
Andrew C. Cohen is a cultural economic sociologist currently working at the innovation agency Phenomenon in Los Angeles, California, and a Culture Industries Fellow at the Yale Center for Cultural Sociology. His dissertation draws on ethnographic research and interviews across four different advertising agencies to examine the ways in which cultural processes shape the various social activities of developing advertisements.

Shai M. Dromi is College Fellow in Sociology at Harvard University. He is a comparativehistorical sociologist with research on organizational culture, global-transnational activism, and morality. His recent articles include 'Soldiers of the cross: The Red Cross and the genesis of the humanitarian field' (Sociological Theory, 2016) and 'For good and country: Nationalism and the diffusion of humanitarianism in the late-nineteenth-century' (The Sociological Review, 2016). His current book project examines the origins and development of the humanitarian NGO sector, and is under contract at the University of Chicago Press. 
Table 1. Description of advertising agencies included in the sample

\begin{tabular}{lllr}
\hline Agency & U.S. Location & Agency Size & Interviews \\
\hline Pioneer & Northeast & Small & 13 \\
Alexander \& Sons & Midwest & Medium & 27 \\
CultureShock & Rocky Mountain Region & Large & 34 \\
\hline
\end{tabular}


Table 2. Summary of three common justifying narratives

\begin{tabular}{|c|c|c|c|}
\hline Narrative & Account-driven & Creative-driven & Strategy-driven \\
\hline Moral object & The Client & The Advertisement & The Consumer \\
\hline $\begin{array}{l}\text { Definition of } \\
\text { the Common } \\
\text { Good }\end{array}$ & $\begin{array}{l}\text { Expert empowerment: by } \\
\text { using their expertise to } \\
\text { care for their clients, } \\
\text { advertising helps clients } \\
\text { realize their goals. }\end{array}$ & $\begin{array}{l}\text { Meaningful inspiration: } \\
\text { by making creative and } \\
\text { well-executed ads, } \\
\text { advertisers give society } \\
\text { beautiful and thought- } \\
\text { provoking objects. }\end{array}$ & $\begin{array}{l}\text { Empathetic understanding: } \\
\text { by researching and } \\
\text { understanding consumers, } \\
\text { advertisers help people fill } \\
\text { gaps in their lives. }\end{array}$ \\
\hline $\begin{array}{l}\text { Fieldwork } \\
\text { example }\end{array}$ & $\begin{array}{l}\text { "I love to be able to create } \\
\text { solutions that people } \\
\text { [clients] need." }\end{array}$ & $\begin{array}{l}\text { "You're still trying to put } \\
\text { something out there that } \\
\text { speaks to people and it's } \\
\text { just plain cool." }\end{array}$ & $\begin{array}{l}\text { "I get to come to work } \\
\text { every day and help } \\
\text { consumers find products } \\
\text { and services that will } \\
\text { make their lives better." }\end{array}$ \\
\hline $\begin{array}{l}\text { Exemplary } \\
\text { text }\end{array}$ & $\begin{array}{l}\text { David Ogilvy’s ([1963] } \\
\text { 2011) Confessions of an } \\
\text { Advertising Man }\end{array}$ & $\begin{array}{l}\text { Luke Sullivan's (2003) } \\
\text { Hey Whipple, Squeeze } \\
\text { This! A Guide to Creating } \\
\text { Great Ads }\end{array}$ & $\begin{array}{l}\text { Jon Steel's (1998) Truth, } \\
\text { Lies \& Advertising: The } \\
\text { Art of Account Planning }\end{array}$ \\
\hline $\begin{array}{l}\text { Text } \\
\text { example }\end{array}$ & $\begin{array}{l}\text { "The relationship between } \\
\text { a manufacturer and his } \\
\text { advertising agency is } \\
\text { almost as intimate as the } \\
\text { relationship between a } \\
\text { patient and his doctor" } \\
\text { (pp. 69-70). }\end{array}$ & $\begin{array}{l}\text { "There is a fork in the } \\
\text { road here. You can follow } \\
\text { Mr. Bernbach [a famed, } \\
\text { influential creative } \\
\text { director] or Mr. Whipple } \\
\text { [an effective but grating } \\
\text { spokesperson]. Mr. } \\
\text { Bernbach's path is the one } \\
\text { I invite you to come } \\
\text { down. It leads to the same } \\
\text { place-enduring brands } \\
\text { and market leadership- } \\
\text { but gets there without } \\
\text { costing anybody their } \\
\text { dignity. You won't have } \\
\text { to apologize to the } \\
\text { neighbors for creating that } \\
\text { irritating interruption to } \\
\text { their sitcom last night" (p. } \\
\text { 14). }\end{array}$ & $\begin{array}{l}\text { "A new model for } \\
\text { advertising is necessary } \\
\text { that is based on the } \\
\text { understanding that } \\
\text { consumers are people and } \\
\text { recognizes that people are } \\
\text { inherently complex, } \\
\text { emotional, unpredictable } \\
\text { creatures, whose } \\
\text { relationships with each } \\
\text { other and with the } \\
\text { "things" (including } \\
\text { brands, products, and } \\
\text { advertising) around them } \\
\text { are more important than } \\
\text { the "things" themselves" } \\
\text { (p. 23). }\end{array}$ \\
\hline
\end{tabular}

